\title{
ДОСЛІДЖЕННЯ ДВОСТУПІНЧАТОГО ФІЛЬТРА ТОНКОЇ ОЧИСТКИ ДИЗЕЛЬНОГО ПАЛЬНОГО
}

\author{
Олег Миронюк, к. т. н., Віктор Шевчук, к. т. н., \\ Ростислав Паславський, к. т. н. \\ Львівський наиіональний аграрний університет, \\ вул. Володимира Великого, 1, м. Дубляни, Львівський р-н, \\ Львівська обл., Украӥна, \\ e-mail:myronyukos@Inau.edu.ua,shevchukvv@Inau.edu.ua,paslavskyjri@Inau.edu.ua
}

https://doi.org/10.31734/agroengineering2021.25.049

\begin{abstract}
Миронюк О., Шевчук В., Паславський Р. Дослідження двоступінчатого фільтра тонкої очистки дизельного пального

Обгрунтована необхідність очистки дизельного пального в системах живлення дизельних двигунів від механічних забруднень і води. Видалення забруднень з пального може здійснюватися з використанням різних методів, в основі яких лежать хімічні, фізико-хімічні і фізичні процеси. Найпоширенішими $є$ фізичні методи очистки та зневоднення пального 3 використанням фільтрувальних пористих перегородок. 3'ясовано переваги та недоліки гідрофобних і гідрофільних фільтрувальних матеріалів. Перспективним $\epsilon$ забезпечення безперервної регенерації гідрофобної фільтрувальної поверхні 3 використанням гідродинамічного ефекту без використання додаткових пристосувань. Матеріалом для гідрофобної перегородки слугувала металева сітка з фторопластовим покриттям. Проведено дослідження 3 визначення ефективності зневоднення пального, водопроникності та гідравлічного опору гідрофобних перегородок із різним прохідним перерізом комірок пор фільтрувального матеріалу. Кращими фільтрувальними властивостями володіє сітка № 004, яка прийнята матеріалом для фільтрувального елементу фільтра тонкої очистки пального. Запропонований фільтр виконаний двоступінчатим. У першому ступені відбувається основна очистка палива від забруднень і води, у другому додаткова очистка та повернення забруднень назад у бак. В обох ступенях використовується фільтрувальний елемент, пориста перегородка якого виконана у вигляді зрізаного конуса 3 гідрофобного матеріалу. Проведено розрахунок габаритних розмірів гідродинамічного фільтра 3 умови рівності потоку пального у всіх його прохідних перерізах. Проведені випробування довели ефективність запропонованого фільтра з водовідокремлення та збільшення його ресурсу роботи порівняно зі серійними фільтрами тонкої очистки дизельного пального.
\end{abstract}

Ключові слова: фільтр тонкої очистки пального, гідрофобна перегородка, гідродинамічний ефект, фільтрувальний елемент.

Mironiuk O., Shevchuk V., Paslavskyi R. Research of the two-stage fine cleaning diesel fuel filter

The article substantiates the necessity of purification of diesel fuel in the power supply systems of diesel engines from mechanical pollution and water, which significantly impairs reliability of the elements of the fuel supply system. Removal of contaminants from fuel can be carried out using various methods, which are based on chemical, physical and chemical, and physical processes. The most common are physical methods of cleaning and dehydration of fuel using filter porous partitions. The advantages and disadvantages of hydrophobic and hydrophilic filter materials are established. It is promising to use a hydrophobic filter surface, the regeneration of which is continuous due to the use of the hydrodynamic effect without the use of additional devices. The material for the hydrophobic partition was a metal mesh with a fluoroplastic coating. Studies have been conducted to determine the efficiency of fuel dehydration, water permeability and hydraulic resistance of hydrophobic partitions with different cross-section of the pore cells of the filter material. The best filtering properties have a grid № 004, which is adopted by the material for the proposed filter element of the fine fuel filter. The proposed filter is made in two stages. In the first stage there is a basic cleaning of diesel fuel from pollution and water, in the second - additional cleaning and return of pollution back to a tank. In both stages, a filter element is used, the porous partition of which is made in the form of a truncated cone of hydrophobic material. The overall dimensions of the hydrodynamic filter are calculated according to the conditions of equality of fuel flow in all its cross-sections. The tests proved the efficiency of the proposed filter for water separation and increase its service life as compared to serial filters for fine cleaning of diesel fuel. The proposed filter provides a cleaning fineness of $3 \mu \mathrm{m}$, to bring the completeness of water separation to $100 \%$, and increases the service life of the filter 3.7 times.

Key words: fine fuel filter, hydrophobic partition, hydrodynamic effect, filter element.

Постановка проблеми. Висока насиченість агропромислового комплексу автотракторною, зернозбиральною та іншою самохідною технікою, осна- щеною дизельними силовими установками, ставить підвищені вимоги до збереження якості пального, що застосовується під час експлуатації такої техніки. 
Важливими результатами вирішення окресленої проблеми є економія пального, продовження ресурсу роботи двигунів і зменшення негативного впливу їхньої експлуатації на навколишнє середовище.

Основним показником якості дизельного палива, здатним різко змінюватися в умовах транспортування, зберігання і заправки, є рівень його чистоти [14]. Джерелами забруднень нафтопродуктів $\epsilon$ механічні домішки й вода, тобто продукти атмосферного і корозійного походження $[7 ; 12]$.

Тому основними напрямами збереження якості дизельного пального $є$ розробка і впровадження заходів зі зниження його забруднення та обводнення. Одним із них $є$ вдосконалення процесу очистки пального безпосередньо в системі живлення дизеля.

Існуюча система очистки дизельного пального не достатньою мірою забезпечує необхідну чистоту цього продукту. Навіть за високого рівня чистоти пального, що заправляється, під час надходження до камери згоряння двигуна воно містить значну кількість забруднень [8; 12; 19]. Тому створення високоефективного засобу очистки пального в системі живлення дизеля $є$ науково-практичним завданням, високоактуальним для сільського господарства й інших галузей, в яких використовуються дизельні двигуни.

Аналіз останніх досліджень і публікацій. Питання, пов'язані зі способами й засобами очистки пального від забруднень і води, розглядалися багатьма вченими $[1-3 ; 17]$. Переважна більшість фахівців стверджує, що для видалення забруднень із пального можна використовувати різні методи на основі хімічних, фізико-хімічних і фізичних процесів. Тверді механічні частинки забруднень у системах живлення двигунів видаляють із пального, як правило, фізичними методами $[10 ; 14]$.

Фізичні методи очистки дизельного пального - очистка в силових полях під впливом гравітаційних, відцентрових, електричних, магнітних, електродинамічних та інших сил, очистка фільтруванням пального через пористі перегородки, а також очистка за допомогою комбінації цих методів.

Найпоширенішими $є$ фізичні методи очистки та зневоднення пального, які можна розділити на три великі групи: під впливом силових полів, із застосуванням пористих перегородок і за допомогою використання теплофізичних явищ (остання група методів застосовується тільки для зневоднення пального і не придатна для його очистки від твердих частинок).

Універсальними пристроями для очистки пального від твердих забруднень є фільтри, ефективність застосування яких практично не залежить від властивостей частинок і пов'язана лише зі співвідношенням цих частинок та розміром пор фільтрувальної перегородки. На роботу фільтрів впливають властивості пального (його в'язкість, електропровідність, наявність у ньому поверхнево-активних речовин тощо) $[2 ; 4 ; 5 ; 10 ; 11]$.

Фільтрувальні методи очистки пального від механічних частинок набули значного поширення завдяки тому, що фільтри, порівняно з іншими пристроями для очистки пального, мають низку переваг, основними 3 яких є стабільна тонкість очистки, відсутність рухомих частин, простота експлуатації $[16 ; 20]$.

Фільтрувальні методи зневоднення пального відрізняються від аналогічних методів видалення $з$ нього твердих частинок. Вони засновані на використанні для відділення вологи пористих перегородок, які можуть виготовлятися 3 матеріалів, що відштовхують (гідрофобні) та поглинають (гідрофільні) воду, а також із поєднанням гідрофільних і гідрофобних волокон [9].

Недоліком використання гідрофобних перегородок $є$ блокування мікрокраплями води пор перегородки, що перешкоджає проходженню через них очищеного пального. У разі використання гідрофільних перегородок ресурс їхньої роботи обмежений часом до повного насичення перегородки вологою і залежить від габаритних розмірів пристрою. Коагулюючі перегородки, що поєднують гідрофобні і гідрофільні волокна, є багатошаровими i мають значні габаритні розміри, а ефективність їхньої роботи значно залежить від швидкості потоку пального, його в'язкості та щільності.

3 перелічених конструкцій фільтрів найпростішими за будовою, малогабаритними i такими, що мають високу здатність відокремлювати воду, є пристрої з гідрофобними перегородками, проте питання відведення з їхньої поверхні затриманих на ній крапель води вимагає вирішення.

Для очистки пального від твердих забруднень застосовуються фільтри різної конструкції, вибір якої залежить від умов експлуатації й вимог до чистоти пального. Фільтри використовуються практично на всіх етапах виробництва, зберігання, транспортування i застосування пального [6]. Основним недоліком фільтрів, що ускладнює їхню 
експлуатацію та обслуговування, є обмежений ресурс роботи, пов'язаний із поступовим закупорюванням пор фільтрувального матеріалу частками забруднень і зростаючим унаслідок цього перепадом тиску на фільтрі до гранично допустимого значення [15].

Аналогічні пристрої використовуються в системах живлення двигунів; при цьому ресурс роботи фільтрувального елементу до його забивання намагаються сумістити 3 терміном чергового технічного обслуговування машини, під час якого й проводиться заміна або промивання фільтрувальних елементів, проте ці проміжки часу найчастіше не збігаються через коливання забруднення пального, що заправляється [19].

Розгляд методів очистки дизельного пального дає підстави для висновку, що перспективним методом для використання в системах живлення дизелів $є$ застосування для цієї мети фільтрувальних перегородок із забезпеченням їх періодичної або безперервної регенерації. За цих умов бажано здійснювати безперервну регенерацію гідрофобної фільтрувальної поверхні 3 використанням гідродинамічного ефекту, що дасть змогу відмовитися від додаткових пристосувань (продувних, промивних або механічних пристроїв), застосування яких неминуче в разі поетапного проведення регенерації на окремих ділянках фільтрувальної поверхні. При цьому блокування гідрофобної поверхні мікрокраплями води не відбуватиметься завдяки їх видаленню 3 цієї поверхні під впливом гідродинамічних сил.

Сутність гідродинамічного ефекту (рис. 1) полягає в тому, що підведення рідини до фільтрувального елементу здійснюється не в радіальному напрямку, як це прийнято за традиційної схеми організації потоку рідини, що очищається, а паралельно поверхні фільтрувального елементу [18]. Використання гідродинамічного ефекту дає змогу підвищити тонкість очистки дизельного пального без зменшення розміру пор фільтрувального елементу і збільшення тим самим його гідравлічного опору, що сприяе підвищенню ресурсу його роботи, а також має забезпечити ефективне зневоднення пального на гідрофобній фільтрувальній перегородці.

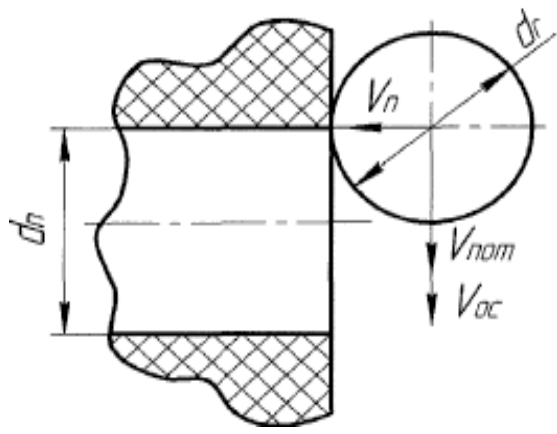

a)

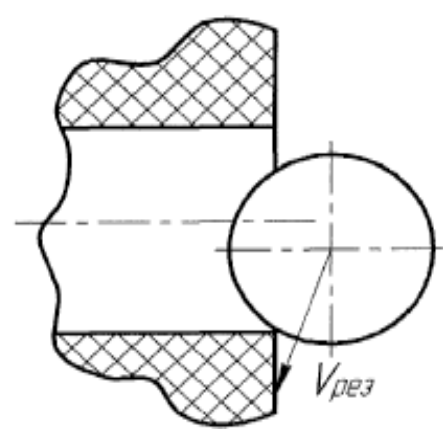

б)

Рис. 1. Схема взаємодії твердої частинки і пори під час гідродинамічного фільтрування:

$a$ - у початковий момент; $\sigma$ - після досягнення частинкою задньої кромки пори; $d_{n}, d_{r}-$ відповідно діаметри пори і частинки, м; $V_{\text {пот }}$ - поздовжня швидкість потоку, м/с; $V_{o c}-$ швидкість осадження частинки, м/с; $V_{p e s}-$ результативна швидкість частинки, м/с; $V_{n}$ - поперечна швидкість потоку, зумовлена перепадом тиску на фільтрувальній перегородці, м/с

Fig. 1. Scheme of interaction of solid particles and pores during hydrodynamic filtration:

$a$ - at the initial moment; $\sigma$ - after the particle reaches the posterior edge of the pore; $d_{p}, d_{r}$-the diameters of the pores and particles respectively, $\mathrm{m} ; V_{p o t}-$ longitudinal flow velocity, $\mathrm{m} / \mathrm{s} ; V_{o c}$ - particle deposition rate, $\mathrm{m} / \mathrm{s} ; V_{r e z}-$ the resulting particle velocity, $\mathrm{m} / \mathrm{s} ; V_{p}-$ the transverse flow rate due to the pressure drop across the filter baffle, $\mathrm{m} / \mathrm{s}$

Частинка забруднень, що переміщується в потоці пального, бере участь у двох рухах: уздовж поверхні пористої перегородки і паралельно осі горизонтально розташованих пор цієї перегородки. Вертикальний рух частинки відбувається за сумарного впливу сили, прикладеної 3 боку потоку, і об'ємної сили, що $є$ різницею гравітаційної і сили Архімеда, а горизонтальний - під впливом сили, зумовленої перепадом тиску на фільтрувальній перегородці. Унаслідок спільної дії цих сил із поверхні перегородки видаляються частинки, розміри яких значно менші за діаметр пор і залежать від швидкості вертикального потоку пального. Одночасно під впливом зазначених сил із перегородки видалятимуться й мікрокраплі води. 
Постановка завдання. Таким чином, робота присвячена розв'язанню актуального науковопрактичного завдання, що полягає в розробці перспективної конструкції засобу забезпечення чистоти дизельного пального з оптимальними техніко-економічними характеристиками для використання в системах живлення дизелів. Метою нашого дослідження $є$ підвищення ефективності очистки і зневоднення дизельного пального під час експлуатації мобільної техніки в умовах сільськогосподарського виробництва.

Виклад основного матеріалу. Як було зазначено, дрібнопористі гідрофобні матеріали, що володіють властивостями фільтрування та відштовхування води, доцільно використовувати в конструкціях пористих перегородок фільтрів тонкої очистки систем живлення дизелів. У роботах [9; 13] наведені результати дослідження різних пористих гідрофобних матеріалів. Встановлено, що кращими гідравлічними властивостями i здатністю відштовхування води володіє металева сітка № 004 з фторопластовим покриттям 4Д, яка обрана для подальших досліджень.

Перегородки зі здатністю відштовхування води для проведення порівняльних випробувань виготовлялися 3 дротяних латунних сіток із квадратними комірками, розмір сторони яких становить відповідно 40, 56, 63, 71 і 80 мкм. Виготовлення такої перегородки полягало в зануренні знежиреної сітки в рідку композицію, іiі висушуванні і спіканні покриття. Після нанесення гідрофобного покриття розмір пор відповідних перегородок зі здатністю відштовхування води становив $\varnothing 20, \varnothing 25,36 \times 36,40 \times 40,48 \times 48$ мкм. Пори сіток № 004 і № 0056 набули майже круглої форми, а пори інших сіток - квадратної форми із заокругленими краями.

Ефективність зневоднення дизельного пального виготовленими перегородками зі здатністю відштовхування води визначалася на різних швидкостях потоку пального 3 початковим вмістом води $0,1 \%$ (мас.). Результати випробувань наведені в табл. 1. Як видно з наведених даних, кращими властивостями 3 відштовхування вологи володіє перегородка, виготовлена зі сітки № 004.

Результати випробувань виготовлених гідрофобних перегородок, що проводилися 3 метою оцінки їх здатності пропускати воду крізь перегородку, наведені в табл. 2.

Залежність здатності проходження води крізь гідрофобні перегородки від живого перерізу їхніх комірок наведена на рис. 2. Зазначена залежність має нелінійний характер, оскільки проникність води крізь перегородки різко зростає зі збільшенням розміру комірок.

Гідравлічні характеристики виготовлених гідрофобних перегородок наведено на рис. 3.

У досліджуваному діапазоні швидкостей потоку пального залежність перепаду тиску на перегородці від швидкості потоку має лінійний характер, тобто підпорядковується закону Дарсі.

Таблиця 1. Ефективність зневоднення пального перегородками зі здатністю відштовхування води Table 1. Efficiency of fuel dehydration by water-repellent partitions

\begin{tabular}{|c|c|c|c|c|c|c|c|c|c|c|}
\hline Номер сітки & \multicolumn{10}{|c|}{ Ефективність відокремлення води, \% } \\
& \multicolumn{10}{|c|}{ за швидкості потоку, м/с $10^{-3}$} \\
\cline { 2 - 13 } & 5,5 & 17,0 & 28,0 & 38,0 & 52,0 & 69,0 & 82,0 & 95,0 & 109,5 & 122,0 \\
\hline 004 & 100 & 99,9 & 99,8 & 99,7 & 99,5 & 99,3 & 99,2 & 98,9 & 98,6 & 98,2 \\
\hline 0056 & 99,9 & 99,8 & 99,8 & 99,6 & 99,4 & 99,1 & 98,8 & 98,7 & 98,5 & 97,9 \\
\hline 0063 & 99,9 & 99,8 & 99,7 & 99,5 & 99,3 & 99,1 & 98,7 & 98,4 & 98,2 & 97,7 \\
\hline 0071 & 99,8 & 99,7 & 99,4 & 99,2 & 99,2 & 99,0 & 98,2 & 97,5 & 96,8 & 91,9 \\
\hline 008 & 99,7 & 99,6 & 99,3 & 99,1 & 99,8 & 98,4 & 97,2 & 96,5 & 94,4 & 90,1 \\
\hline
\end{tabular}

Таблиця 2. Проникність води крізь перегородки зі здатністю відштовхування води

Table 2. Water permeability of moisture-repellent partitions

\begin{tabular}{|c|c|c|}
\hline Номер сітки & $\begin{array}{c}\text { Площа перерізу комірки, } \\
\text { мкм }^{2}\end{array}$ & $\begin{array}{c}\text { Тиск проштовхування води, } \\
\text { мм вод. ст. }\end{array}$ \\
\hline 004 & 322 & 228 \\
\hline 0056 & 522 & 173 \\
\hline 0063 & 1296 & 155 \\
\hline 0071 & 1600 & 151 \\
\hline 008 & 2304 & 148 \\
\hline
\end{tabular}




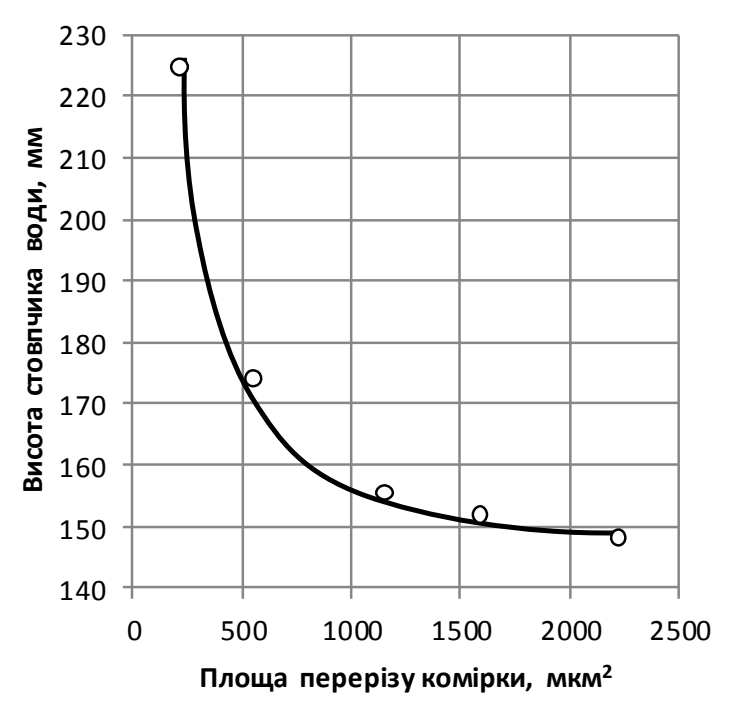

Рис. 2. Проникність води крізь гідрофобні перегородки з різним розміром комірок

Fig. 2. Water permeability of hydrophobic partitions with different cell sizes

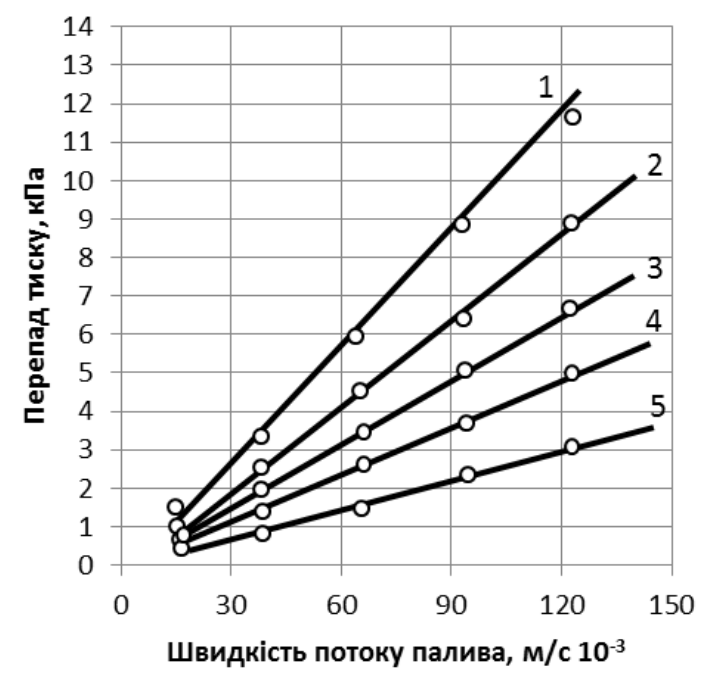

Рис. 3. Гідравлічні характеристики гідрофобних перегородок, виготовлених

із сіток: 1 - 004; 2 - 0056; 3 - 0063; $4-0071 ; 5-008$

Fig. 3. Hydraulic characteristics of hydrophobic partitions made of grids: $1-004 ; 2-0056 ; 3-0063$;

$$
4-0071 ; 5-008
$$

Як уже було зазначено, під час використання гідрофобних пористих перегородок для очистки дизельного пального від механічних забруднень та емульсійної води запобігти закупорюванню пор перегородки твердими частинками і блокуванню їх мікрокраплями води, а також збільшити тонкість очистки пального можна за допомогою використання гідродинамічного ефекту.
У традиційних фільтрах для очищення рідин від твердих забруднень рідина, що очищується, надходить до пористої перегородки в радіальному напрямку. Недоліком таких фільтрів $є$ досить швидке закупорювання пор перегородки частинками забруднень, а також нездатність видаляти емульсійну воду.

Це питання успішно вирішується під час очищення рідин у циркуляційних системах, де частина рідини використовується для створення потоку вздовж перегородки і відводиться назад у паливний бак.

Позитивний результат досягається тим, що в пристрої для очищення дизельного пального пориста перегородка фільтрувального елементу виконана у вигляді зрізаного конуса 3 гідрофобного матеріалу, фільтрувальний елемент у нижній частині розташований у конічному патрубку скидання частини рідини, що йде на очистку. Днище корпусу виконане перфорованим для проходу очищеного дизельного пального. У циліндричній насадці зі зовнішнього боку днища розміщений додатковий гідродинамічний фільтрувальний елемент, що містить пористу перегородку, також виконану у вигляді зрізаного конуса $з$ гідрофобного матеріалу, верхня і нижня основи якого з'єднані відповідно 3 патрубком скидання частини очищеного дизельного пального і патрубком для зливу відстою.

Схему будови запропонованого фільтра для очистки дизельного пального від забруднень зображено на рис. 4.

Фільтр містить циліндричний корпус 1 , герметично встановлену на ньому кришку 3 з вхідним патрубком 4. Усередині корпусу 1 за допомогою натискної пружини 5 i диска 7 встановлений основний фільтрувальний елемент 8 , виконаний у вигляді зрізаного конуса.

На днищі 9 розташований патрубок скидання частини неочищеного дизельного пального, у нижній циліндричній частині якого за допомогою упорної гайки 10 приєднана насадка 11 додаткового фільтрувального елементу 12. Його конічний патрубок у нижній частині герметично встановлений у патрубку зливу відстою, розміщеному на днищі 13. Корпус у вертикальній стінці має патрубок 14 для відведення очищеного дизельного пального, що надходить у зовнішню порожнину через отвори в днищі 9 і через пористу перегородку додаткового фільтрувального елементу 12.

Для забезпечення рівномірної подачі пального на робочу поверхню пористої перегородки i однакового тиску на вході за всією іiі висотою фільтрувальний елемент повинен мати криволі- 
нійну форму, що забезпечує змінну ширину його внутрішньої порожнини. Оптимальною формою перегородки для забезпечення рівномірної подачі на неї пального є зрізаний параболоїд, проте для практичних цілей 3 технологічних міркувань можна прийняти форму фільтрувального елементу у вигляді зрізаного конуса. У цьому разі вектор швидкості частинки під дією сили потоку пального може не збігатися 3 вертикальним напрямком, проте рух потоку рідини в просторі, що звужується, з одночасним відведенням частини рідини через пористу перегородку можна 3 достатнім ступенем ймовірності вважати вертикальним.

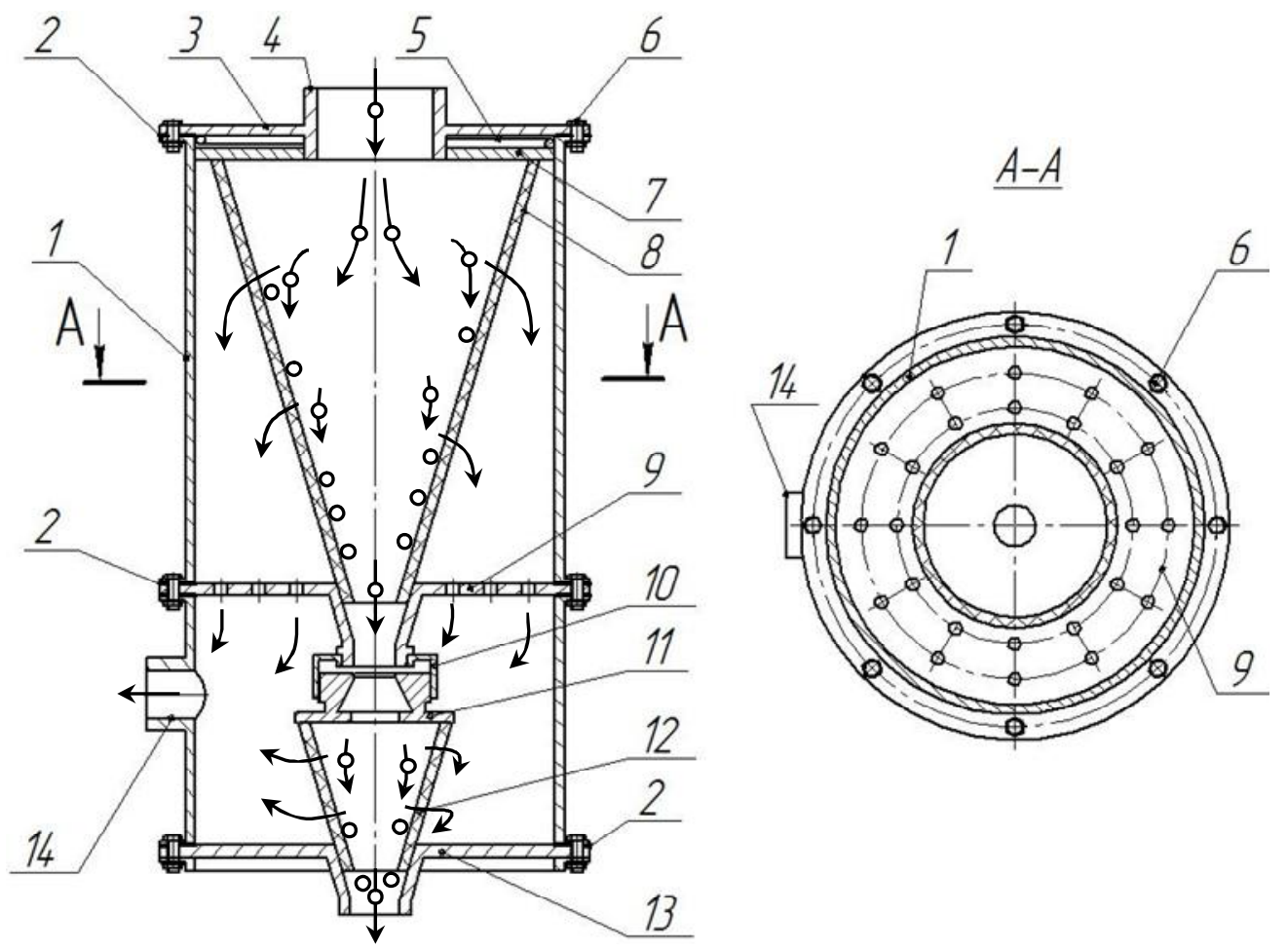

Рис. 4. Фільтр для очистки дизельного пального від забруднень:

1 - корпус; 2 - прокладка; 3 - кришка; 4 - вхідний патрубок; 5 - натискна пружина;

6 - болтове з'єднання; 7 - диск; 8 - основний фільтрувальний елемент; 9 - перфороване днище; 10 - упорна гайка; 11 - насадка; 12 - додатковий фільтрувальний елемент; 13 - днище з патрубком зливу відстою; 14 - патрубок відведення очищеного пального

Fig. 4. The filter for cleaning of diesel fuel from pollution:

1 - housing; 2 - gasket; 3 - cover; 4 - inlet pipe; 5 - compression spring; 6 - bolted connection; 7 - disk; 8 - the main filter element; 9 - perforated bottom; 10 - thrust nut; 11 - nozzle; 12 - additional filter element; 13 - the bottom with a branch pipe of drain of a sludge; 14 - branch pipe removal of the cleared fuel

Подача пального до внутрішньої порожнини фільтрувальних елементів забезпечує найкращі умови для відведення затриманих на пористих перегородках твердих частинок і мікрокрапель води, а конусна форма цих перегородок звужується в напрямку потоку пального. Це зумовлено необхідністю забезпечення його поздовжнього переміщення 3 постійною швидкістю вздовж поверхні пористих перегородок, що забезпечує однаковий гідравлічний опір у всіх точках цих поверхонь. У фільтрувальних елементах однаковий гідравлічний опір досягається завдяки вибору співвідношення їхніх робочих поверхонь 1:10, оскільки об'єм пального, що створює поздовжній потік уздовж внутрішньої поверхні пористої перегородки, який надходить для очистки в додатковий фільтрувальний елемент, становить $7-10 \%$ від об'єму всього пального, що очищується в пристрої.

Ефект, отриманий під час роботи пристрою, досягається завдяки тому, що частина дизельного пального, яка надходить на скидання, проводить змив забруднень із поверхні пористої перегородки, далі очищається в додатковому гідродинамічному фільтрувальному елементі під час проходження через його пористу перегородку, 
зменшуючи кількість відстою, що видаляється 3 пристрою через патрубок, до 1 \% від загального обсягу пального, що надходить на очистку.

Розроблений пристрій для очистки дизельного пального працює таким чином. Забруднене пальне під тиском подається у вхідний патрубок, звідки надходить у верхню внутрішню порожнину, що звужується, утворену пористою перегородкою, проходить через пори цієї перегородки, надходить у кільцевий зазор між корпусом і пористою перегородкою і відводиться через отвори в днищі корпусу в нижню зовнішню порожнину, а частина пального створює поздовжній потік уздовж внутрішньої поверхні основної пористої перегородки i звідти надходить у внутрішню порожнину пористої перегородки додаткового гідродинамічного фільтрувального елементу, проходить через пори цієї перегородки і надходить у зовнішню порожнину, звідки відводиться через патрубок для відведення очищеного пального разом із пальним, що надійшло через отвори в днищі, а пальне, що створює поздовжній потік уздовж внутрішньої поверхні пористої перегородки додаткового гідродинамічного фільтра і $\epsilon$ концентрованою суспензією, насиченою механічними забрудненнями, емульсійною водою, видаляється через патрубок зливу відстою. Результати випробувань наведені в табл. 3.

Таблиця 3. Результати випробувань пристрою для очистки дизельного пального

Table 3. Test results of the device for cleaning diesel fuel

\begin{tabular}{|c|c|c|}
\hline Види забруднень & $\begin{array}{c}\text { Дизельне пальне } \\
\text { до очистки }\end{array}$ & $\begin{array}{c}\text { Дизельне пальне } \\
\text { після очистки }\end{array}$ \\
\hline Механічні домішки, кг/м ${ }^{3}$ & 0,06 & $<0,001$ \\
\hline Емульсійна вода, мг/м ${ }^{3}$ & 253 & $<0,01$ \\
\hline
\end{tabular}

Під час розрахунку основних конструктивних та експлуатаційних параметрів фільтра тонкої очистки пального в системі живлення дизеля на підставі заданої тонкості фільтрування та пропускної здатності цього пристрою визначаються габаритні розміри i прохідні перерізи окремих його частин.

Визначення габаритних розмірів гідродинамічного фільтра здійснюється 3 умови рівності потоку пального у всіх прохідних перерізах пристрою. 3 умови нерозривності потоку отримаємо:

$$
v=\frac{Q}{S},
$$

де $v$ - швидкість потоку пального, м/с; $Q$ пропускна здатність пристрою, $\mathrm{m}^{3} / \mathrm{c} ; S-$ площа прохідного перерізу, м².

Тоді верхній і нижній діаметри фільтрувального елементу дорівнюють:

$$
D_{s}=\frac{4 Q_{6 x}}{\pi v} ; D_{н}=\frac{4 Q_{6 u x}}{\pi v},
$$

де $Q_{b x}, Q_{\text {вих }}$ - відповідно пропускна здатність гідродинамічного фільтра на вході у фільтрувальний вологовідштовхувальний елемент і під час скидання частини пального в динамічний відстійник, $\mathrm{m}^{3} / \mathrm{c}$.

Якщо $v=$ const, площа кожного поперечного перерізу фільтрувального елементу буде прямо пропорційна витраті палива, що очищається в цьому перерізі. Оскільки надходження пального до елементу має відбуватися рівномірно за всією його висотою, зазначена залежність має лінійний характер:

$$
S=\frac{\pi}{4 D_{\text {вн. }}^{2}},
$$

де $D_{\text {вн. }}$ - діаметр фільтрувального елементу на висоті $x$, м.

Витрата палива в перерізі, що знаходиться на висоті $x$, становитиме:

$$
Q_{x}=\frac{Q_{6 x . x}}{H},
$$

де $x$ - поточна координата висоти фільтрувального елементу, м; $H$ - висота фільтрувального елементу, м.

У такому разі

$$
\alpha=\operatorname{arctg} \frac{Q_{b x . x}}{H},
$$

де $\alpha$ - кут конусності бічної поверхні елементу, град.

Під час розрахунку розмірів фільтрувального елементу, що являє собою зрізаний конус, приймаємо площу меншої основи конічної перегородки, що дорівнює 10 \% iii верхньої основи: $S_{H}=0,1 S_{B}$.

Розміри фільтрувального елементу вибираємо рівними розмірам серійних фільтроелементів фільтрів тонкої очистки пального [5]: найбільший діаметр $D_{b}=92 \mathrm{мм}$, висота $H=115$ мм. Використовуючи формули (4) i (5), отримаємо: $\operatorname{arctg} \alpha=5,7 ; \alpha=80^{\circ}$.

Аналогічно проводяться розрахунки додаткового гідродинамічного фільтрувального елементу з габаритними розмірами: $D_{b}=42 \mathrm{Mм}, H=38$ мм.

Висновки. Для підвищення ефективності очистки та зневоднення дизельного пального під час 
експлуатації мобільної техніки визначено напрями вдосконалення системи очистки дизельного пального, що передбачають підвищення експлуатаційних показників фільтра тонкої очистки - тонкості фільтрування, ресурсу роботи, а також надання пристрою функцій відштовхування вологи.

Досліджено пористі перегородки для очистки та зневоднення дизельного пального і встановлено, що найкращими експлуатаційними властивостями володіє фільтрувальна перегородка 3 властивістю відштовхування води, виготовлена на основі металевої сітки № 0043 нанесеним гідрофобним покриттям, яка рекомендована для використання у фільтрах тонкої очистки систем живлення дизелів.

Проведено порівняльні випробування, які підтвердили високу ефективність використання гідродинамічного ефекту під час конструювання фільтра тонкої очистки пального системи живлення дизеля і рекомендовано застосування гідродинамічного фільтра як робочого ступеня цього пристрою.

Дослідження фільтра тонкої очистки показали, що застосування дрібнопористих гідрофобних матеріалів із металевої сітки 3 фторопластовим покриттям, що володіють фільтрувальними властивостями і здатністю відштовхування вологи, під час використання гідродинамічного ефекту дозволяє забезпечити тонкість очистки 3 мкм, довести повноту відділення води до $100 \%$ і збільшити ресурс роботи фільтра в 3,7 раза.

Унаслідок проведених досліджень розроблена конструкція пристрою для забезпечення чистоти дизельного пального в системі живлення, що містить гідродинамічний фільтр тонкої очистки пального. Експлуатаційні випробування цього пристрою показали його високу ефективність.

\section{Бібліографічний список}

1. Андрианова Г. П. Физико-химические основы создания модификаций многослойных композиционных пористых и волокнисто-пористых полимерных материалов. Дизайн и технологии. 2010. № 17(59). С. 70-81.

2. Бродский Г. С. Фильтры и системы фильтрации для мобильных машин. Москва: Горная пром-сть, 2004. $260 \mathrm{c}$.

3. ГОСТ 6370-83. Нефть, нефтепродукты и присадки. Метод определения механических примесей. Москва: Стандартинформ, 2008. $11 \mathrm{c.}$

4. Грачева К. Топливные фильтры для длительной эксплуатации двигателя. Автотранспорт: эксплуатащия $u$ ремонт. 2018. № 1-2. С. 44- 46.

5. Деревянченко С. О., Ливенцев Д. Н., Королев А. И. Современные фильтрующие элементы автомобиля. Наука и образование на современном этапе развития: опыт, проблемы и пути их решения: материалы Междунар. науч.-практ. конф. Воронеж, 2018. С. 266-272.

6. Коваленко В. П., Улюкина Е. А., Воробьёв А. Н. Современные методы очистки автомобильного топлива от механических загрязнений и воды. Техника и технологии агропромышленного комплекса. 2011. № 2. С. 23-25.
7. Кулаков Ю. М. Як позбавитися від води в баку. Автодвор. 2016. № 9 (162). С. 11.

8. Кюрчев С. В., Юдовинський В. Б., Коломоєць В. А. Надійність паливної системи ДВЗ, працюючих на різних видах палива. Вісник Харківського національного технічного університету сільського господарства ім. П. Василенка. 2014. Вип. 148: Механізація сільського господарства. С. 314-320.

9. Лебедев В. В., Коваленко В. П., Симоненко А. В. Химические и физико-химические методы обезвоживания топлив. Тракторы и сельхозмашины. 2002. № 7. C. 21-22.

10. Поливаев О. И., Ведринский О. С., Мурзин М. С., Демидов И. А. Обзор топливных фильтров для очистки дизельного топлива в силовых полях. Hовые технологии и технические средства для эффективного развития АПК: материалы науч.-практ. конф. Воронеж, 2019. C. 98-104.

11. Тарасов Ю. С., Татаров Л. Г., Галкин М. М. Топливный фильтр. Научное обеспечение агропромышленного производства: материалы Междунар. науч.-практ. конф. Курск, 2010. С. 260-264.

12. Тарасов Ю. С., Татаров Л. Г., Молочников Д. Е. Виды загрязнения топлива и его очистка. Использование инновачионных технологий для решения проблем АПК в современных условиях: материалы Междунар. науч.-практ. конф., посвященной 65-летию образования Волгоградской государственной сельскохозяйственной академии. Волгоград, 2009. С. 219-223.

13. Тимофеев С. С. Повышение ресурса деталей плунжерных пар. Збірник наукових праџь УкрДАЗТ. 2013. Вип. 136. С. 257-260.

14. Удлер Э. И., Исаенко В. Д., Исаенко П. В., Исаенко А. В. Повышение чистоты дизельного топлива при эксплуатации машин. Bопросы современной науки: проблемы, тендениии и перспективы: материалы Междунар. науч.-практ. конф. Ульяновск, 2017. С. 113-116.

15. Удлер Э. И., Исаенко В. Д., Исаенко П. В., Исаенко А. В. Повышение эффективности топливной системы дизельных машин. Актуальные вопросы науки и техники: сб. науч. тр. по итогам Междунар. науч.-практ. конф. Самара, 2015. С. 53-56.

16. Удлер Э. И., Исаенко П. В., Готовцева Т. А., Зыков С. А. Топливные фильтроэлементы на основе деформируемых пенополиуретанов. Международный научный журнал. 2013. № 5. С. 91-95.

17. Удлер Э. И., Шевченко Н. Н., Давыдов А. В. Комплексная система обеспечения чистоты дизельного топлива при эксплуатации сельскохозяйственной техники. Вестник Башкирского государственного аграрного университета. 2017. № 1(41). С. 74-79.

18. Финкельштейн 3. Л. Применение и очистка рабочих жидкостей для горных машин. Москва: Недра, 1986. $233 \mathrm{c}$.

19. Халтурин Д. В., Лысунец А. В., Немцев А. Б. Состояние и инновации технического сервиса машин и оборудования. Х региональная научно-практическая конференция: материалы. Новосибирск, 2018. С. 310-315.

20. Хаматов Ф. И., Нурмиев А. А. Обзор конструкций топливных фильтров. Наука аграрному производству: материалы науч. конф. Казань, 2018. С. 84-88. 